\title{
PENGARUH KEPRIBADIAN DAN PENGALAMAN TERHADAP EFEKTIFITAS MANAJERIAL KEPALA SEKOLAH SMP NEGERI DI WILAYAH JAKARTA TIMUR
}

\author{
Serepina Tiurmaida *
}

\begin{abstract}
The objective of this research is to study information about the effect of personality and experience on the managerial effectiveness. The research was conducted to all of State Junior High Schools Principals in The City of East Jakarta by using a survey method with path analysis applied in testing hypothesis. The sample size in the research was done to 77 principals with samples taken using simple random sampling. The result shows that there are direct influence of the followings: (1) there is positively direct effect of personality on the managerial effectiveness. (2). there is positively direct effect of experience on the managerial effectiveness. (3) there is positively direct effect of personality on the experience. It is expected that the results of the research could be implied in increasing and optimalizing the managerial effectiveness, personality and experience should be taken into account.
\end{abstract}

Keywords: personality, experience and managerial effectiveness.

\section{PENDAHULUAN}

Kepala sekolah sebagai pimpinan tertinggi yang sangat berpengaruh dan menentukan kemajuan sekolah harus memiliki kemampuan manajerial, memiliki yang mampu mengarahkan, mempengaruhi, membimbing dan memberi teladan yang konstruktif kepada bawahan atau pengikutnya serta unjuk kebolehan atau kontribusi bagi kolega maupun atasannya dalam proses pencapaian tujuan organisasi. Keberhasilan setiap unit organiasi atau sekolah di dalam organisasi tergantung kepada keefektifan kepemimpinan orang yang memegang posisi pimpinan. Efektivitas manajerial dapat mengantisipasi perubahan, pemanfaatan kesempatan sebaik-baiknya ke arah meningkatnya suatu organisasi ke dalam pencapaian tujuan yang telah disepakati.

Masih rendahnya mutu pendidikan di Indonesia pada saat ini merupakan isu yang masih tetap muncul ke permukaan. Isu tersebut merupakan suatu masalah yang perlu di carikan jalan keluarnya oleh berbagai pihak khususnya yang terkait dengan pendidikan, sehingga dapat terselesaikan. Masalah rendahnya mutu pendidikan tidak bisa di pungkiri, karena mengkaji tentang mutu keberhasilan yang di tentukan oleh berbagai faktor, baik sistem maupun prosesnya.

Kepala sekolah bertanggung jawab terhadap semua aktivitas lembaga pendidikan, untuk itu diperlukan kepala sekolah yang memiliki kemampuan manajerial dalam melaksanakan fungsi manajemen di sekolah. Di sinilah, efektifitas manajerial kepala sekolah dibutuhkan dan dengan kepribadian dan pengalaman yang dimiliki seorang kepala sekolah akan mendapatkan kepercayaan dari orang-orang yang ada di bawahnya secara positif. Sebagaimana Ngalim Purwanto dalam bukunya Administrasi Pendidikan menyatakan bahwa, selain syarat ijazah sebagai syarat formil pengangkatan seorang kepala sekolah, juga perlu diperhatikan pengalaman dan kepribadian. Adanya

\footnotetext{
* Dosen pada Sekolah Tinggi Ilmu Ekonomi (STIE) di Jakarta Timur.
} 
kriteria pengangkatan kepala sekolah dibuat dengan tujuan agar pelaksanaan proses pendidikan di setiap satuan pendidikan dapat berjalan sesuai dengan harapan dan tujuan pendidikan dalam peningkatan mutu pendidikan dapat tercapai.

Pada kenyataannya di lapangan masih terdapat sejumlah fakta bahwa kepala sekolah diduga kurang optimal dalam menjalankan fungsinya sebagai kepala sekolah. Rendahnya efektifitas manajerial kepala sekolah dalam melaksanakan proses manajemen yang merujuk pada fungsi-fungsi manajemen, juga dituntut untuk memahami sekaligus menerapkan seluruh substansi kegiatan pendidikan. Ini menandakan bahwa dalam mengelola pendidikan merupakan garapan yang kompleks, sehingga perlu penanganan menyeluruh, melibatkan berbagai pihak.

\section{Efektivitas Manajerial}

Reddin yang dikutip Laurie J. Mullins (2005:260) menjelaskan bahwa, "managerial effectiveness has to be defined in terms of output rather than input, by what a manager achieves rather than by what he does". Efektivitas manajerial didefinisikan sebagai hasil keluaran daripada masukan, dengan apa yang manajer hasilkan dari pada yang manajer kerjakan). Laurie J Mullins (2005:263), "managerial effectiveness results from a combination of personal attributes and dimensions of the manager's job in meeting the demands of the situation, and satisfying the requirements of the organization". Hasil dari efektivitas managerial adalah sebuah kombinasi atribut pribadi dan dimensi pekerjaan manajer dalam memenuhi tuntutan situasi dan memuaskan persyaratan organisasi.

Laurie J. Mullins (2005:265) menyatakan criteria dari efektivitas yaitu: "criteria of general effectiveness allocation of resources, achieving purpose, goal attainment, planning, organising, co-ordinating, controlling". Kriteria dari efektivitas secara umum adalah mengalokasikan sumber daya manusia, menghasilkan tujuan, pencapaian tujuan, perencanaan, pengorganisasian, kerjasama, pengawasan.

Jean Brittain Leslie (2002:3-4) dalam konteks globalnya efektifitas manajerial menjelaskan bahwa: (1) Personality stands for an individual's enduring traits that might help explain the kinds of experiences to which he or she is drawn and the kinds of capabilities and role behaviors he or she is most likely to have acquired (2) Experience refers to those experiences and demographic variables that individuals bring with them to the job (3) Managerial capabilities includes three major categories of skills: learning behaviors, resilience, and business knowledge. Learning behaviors include the motivation and skill to work and learn across cultural differences, the willingness to take the perspective of others, and the capacity to learn from workplace experiences. Resilience refers to the ability to manage time and stress, factors that might be more salient when he management task is global in scope. business knowledge, represents knowledge of business and business practices (4) Managerial roles stands for those behaviors that managers employ to carry out the basic functions of their work: managing relationships, managing information, and managing action (5) Global complexity represent the context of interest. Efektivitas manajerial dapat di lihat dari kepribadian seseorang, sifat abadi individu yang mungkin membantu menjelaskan jenis-jenis pengalaman dan jenis-jenis kemampuan dan perilaku peran atau yang telah diperoleh oleh seseorang. Mengacu pada pengalaman dan demografis individu atau seseorang untuk sebuah pekerjaan.

Perlunya kemampuan manajerial yang meliputi tiga kategori utama keterampilan yaitu: perilaku belajar, ketahanan, dan pengetahuan bisnis. Perilaku belajar termasuk motivasi dan keterampilan untuk bekerja dan belajar di perbedaan budaya, kesediaan untuk mengambil perspektif orang lain, dan kapasitas untuk belajar dari pengalaman di tempat kerja. Ketahanan mengacu pada kemampuan untuk mengelola waktu dan stres, 
faktor-faktor yang mungkin lebih menonjol ketika ia tugas manajemen dalam lingkup global. pengetahuan bisnis, merupakan pengetahuan tentang praktek bisnis dan bisnis. Peran manajerial yang memiliki perilaku yang mempekerjakan pimpinan untuk melaksanakan fungsi-fungsi dasar dari pekerjaan yang baik, dapat dilihat dari hubungan mengelola informasi, dan tindakan pengelolaan. Ini semua merupakan kompleksitas global untuk mewakili konteks dari kepentingan sebuah organisasi).

Henry Fayol yang dikutip oleh Garreth R. Jones dan Jennifer M. George (2006:30), menguraikan sifat kegiatan manajerial dilihat dari empat fungsi manajemen yaitu fungsi perencanaan yang mengidentifikasi dan memilih tujuan dan tindakan yang tepat. Pengorganisasian sebuah proses yang digunakan oleh manajer untuk membangun struktur hubungan kerja yang memungkinkan anggota organisasi untuk berinteraksi dan bekerja sama untuk mencapai tujuan organisasi. Dalam mengorganisir, pemimpin juga mengetahui tata letak garis wewenang dan tanggung jawab antara individu dan kelompok yang berbeda, dan mereka memutuskan bagaimana cara terbaik untuk mengkoordinasikan sumber daya organisasi, sumber daya manusia khususnya. Pimpinan mengevaluasi seberapa baik suatu organisasi mencapai tujuan dan mengambil tindakan untuk mempertahankan atau meningkatkan kinerja. Hasil dari proses pengendalian adalah kemampuan untuk mengukur kinerja secara akurat dan mengatur efisiensi dan efektivitas organisasi.

Pendapat dari Mukhneri (2008:2) yang menyatakan bahwa, "manajemen merupakan subjek yang sangat penting dalam organisasi yang berfungsi sebagai alat untuk menetapkan tujuan. mengidentifikasikan kegiatan, menganalisa dan mengkoordinasikan orang-orang dalam organisasi dengan mendayagunakan segala bentuk materil, manusia, sarana dan prasarana yang ada sehingga terwujud efisiensi dan efektifitas organisasi. Ainee Juares dalam tulisannya what is the meaning managerial effectiveness yaitu: "managerial effectiveness is a leader's ability to achieve desired results. How well he applies his skill and abilities in guiding and directing others determines whether he can meet those results effectively. If he can, his achievements are poised to help the organization gain competitive edge against rival organization heading into to future". Implikasinya yaitu bahwa efektivitas manajerial merupakan kemampuan manajer untuk mencapai hasil-hasil yang diinginkan, bagaimana ia mengaplikasikan ketrampilan dan kemauan dalam membimbing dan mengatakan orang lain untuk mencapai tujuan secara efektif, dan efektifitas menajerial akan membantu organisasi menciptakan keunggulan kompetitif yang sejalan dengan perubahan lingkungan organisasi yang cepat.

Gareth R. Jones and Jennifer M. George (2006:30) juga mengungkapkan bahwa, "effective management means managing these activites succesfully". Manajemen yang efektif berarti mengelola aktivitas-aktivitas itu dengan sukses. Selanjutnya Made Pidarta (2004:19) menyatakan bahwa, "efektivitas manajer hanya bisa terwujud bila manajer mampu melaksanakan perannya sebagai manajer untuk mencapai tujuan organisasi yang telah telah di tetapkan".

Gary Yukl (2010:48), menyatakan bahwa, " the competencies related to managerial effectiveness included personality traits, motives, cognitive skill, and interpersonal skills". Kompetensi yang berkaitan dengan efektifitas manajerial adalah termasuk ciri-ciri dari kepribadian, motif, keterampilan kognitif dan keterampilan interpersonal skill. Veithzal dan Deddy (2011:24) menyatakan bahwa: "Kriteria manajerial adalah tingkat energi dan toleransi terhadap stress, rasa percaya diri, integritas, motivasi kekuasaan, orientasi pada keberhasilan, kebutuhan akan afiliasi yang rendah, ketrampilan tehnis, ketrampilan antar pribadi dan ketrampilan konseptual". 
Berdasarkan konsep di atas dapat disintesiskan efektivitas manajerial adalah hasil keluaran dari kombinasi atribut pribadi dan dimensi pekerjaan dalam ketepatan melaksanakan fungsi manajemen melalui orang lain secara optimal dengan indikator: alokasi sumberdaya manusia, pencapaian tujuan, berkoordinasi dengan orang lain, kemauan dalam membimbing, dan pelaksanaan pengawasan.

\section{Kepribadian}

Jerald Greenbarg (2010:68) menyatakan bahwa, "personality is the unique and relatively stable pattern of behavior, thoughts, and emotions shown by individuals". Kepribadian adalah pola yang unik dan relatif stabil perilaku, pikiran, dan emosi yang ditunjukkan oleh individu. Berbeda dengan Santrock (2008:35) "personality refers to distinctive thoughts, emotions, and behaviors that characterize the way an individual adapts to the world". Kepribadian adalah perbedaan pikiran, emosi dan perilaku yang memberikan karakteristik terhadap cara individu dalam beradaptasi dengan dunia. individu bereaksi sebagai sebuah sistem untuk berbagai situasi, dengan pengalaman yang pas dan niat masa depan berkontribusi untuk menyajikan perilaku.

Sementara Ivancevich, Konopaske dan Matteson (2008:74) kepribadian yaitu: "personality is a term used to describe a great many feeling and behaviors". Kepribadian adalah istilah yang digunakan untuk menggambarkan berbagai perasaan yang hebat dan perilaku. Ryckman (2008:4) menyatakan bahwa, "personality is the dynamic and organized set of characteristics possessed by a person that uniquely influences his or her cognitions, motivations, and behaviors in various situations. It can also be thought of as a psychological contruct, a complex abstraction that encompasses the person's unique genetic background and learning history, and the ways in which these factor influence his or her responces to various environments or situation. Kepribadian adalah organisasi dinamik yang dimiliki seseorang, yang secara unik mempengaruhi kognitif, motivasi, dan perilaku dalam berbagai situasi. Kepribadian dapat juga merupakan konstruk psikologis sebagai abstaksi komplek tentang diri individu. Konstruk psikologis ini terbentuk melalui proses belajar individu yang secara unik, latar belakang genetis atau bawaan serta interaksi kedua hal tersebut, dan mempenaruhi respons individu terhadap stimulus dari lingkungannya.

Robert Kreitner dan Angelo Kinicki (2010:133) mendefinisikan kepribadian adalah: "personality is defined as the combination of stable physical and mental characteristics that give the individual his or her identity. These characteristics or including how one looks, think, acts and feels are the product of interacting genetic and environmental influences". Kepribadian merupakan perpaduan kestabilan fisik dan mental yang memberikan karakteristik individu atau identitasnya. Karakteristik-karakteristik tersebut meliputi bagaimana seseorang melihat, berpikir, bertindak dan merasa adalah hasil dari interaksi genetic dan pengaruh lingkungan. Passer dan Smith (2007:442) mendefinisikan kepribadian yaitu, "personality as the distinctive and relatively enduring ways of thinking, feeling, and acting that characterize a person's responses to life situations". Kepribadian sebagai cara yang khusus dan relatif abadi berpikir, merasa, dan bertindak yang mencirikan respon seseorang terhadap situasi kehidupan.

Selanjutnya Achua Lussier (2010:29) mendefinisikan, "personality is a combination of traits that classifies an individuals's behavior". Kepribadian adalah kombinasi dari ciriciri yang mengklasifikasikan perilaku individu. Lussier (2010:30-31) membagi lima model besar kepribadian, "the big five model of personality categorizes traits into the dimensions of surgency, agreeableness, adjustment, conscientiousness, and openess to 
experience". Model lima besar kepribadian mengkategorikan ciri ke dalam dimensi surgency, keramahan, penyesuaian, kesadaran, dan keterbukaan terhadap pengalaman.

Sedangkan menurut Greenberg (2010:72) ada lima dimensi dasar kepribadian yaitu, "five basic dimensions of personality that are assumed to underlie many specific traits: 1) extraversion 2) agreeableness 3) conscientiousness 4) neuroticism 5) openess to experience". Diasumsikan mendasari banyak sifat khusus yaitu 1) ekstraversi 2) kemampuan untuk bersepakat 3) sifat mendengarkan suara hati 4) stabilitas emosional 5) terbuka pada pengalaman. Fred Luthans (2008:133) dimensi dari kepribadian terdiri dari: individu yang memiliki sifat berhati-hati dan karakteristiknya dapat diandalakan, pekerja keras, teratur, disiplin dari, gigih, bertanggung jawab. Individu yang memiliki emosi yang stabil tinggi pembawaannya selalu tenang, aman, bahagia, dan tidak khawatir.

Berdasarkan konsep di atas dapat disintesiskan kepribadian adalah karakteristik seseorang dalam melihat, berpikir dan berperilaku yang unik yang kesatuan fisik dan psikologisnya komplek dan dinamis dalam diri individu yang berbeda dengan orang lain di dalam lingkungannya dengan indikator: kenyamanan, keramahtamahan, kesadaran, stabilitas emosional, dan keterbukaan terhadap pengalaman.

\section{Pengalaman}

Sabine Sonnentag (2002:197) menyatakan bahwa, "the experience is that job competencies and competencies that apply for high potentials may differ over countries, organisations and jobs". Pengalaman adalah sebuah kompetensi pekerjaan dan kompetensi yang berlaku untuk potensi yang lebih tinggi di dalam suatu organisasi tempat seseorang bekerja. Steve Ward (2009:9) definisi pengalaman yaitu: "experience is one of the most important factors behind consistently successful traders, and experience is purely an outcome of time". Pengalaman adalah salah satu faktor paling penting di balik sukses konsistennya seseorang dan pengalaman adalah hasil murni dari waktu yang di lewati oleh seseorang dalam sebuah organisasi.

Dewey (2009:9) menyatakan bahwa, "keyakinan pada semua pendidikan yang sejati berlangsung melalui pengalaman bukan berarti semua pengalaman pada dasarnya edukatif". Mathis dan Jackson (2002:57) mendefinisikan pengalaman adalah bagian penting dari manajemen. David Ulrich (2006:362-363) menjelaskan bahwa, "Experience is an important part of management development. Indeed, experience often contributes more to the development of senior managers than class-room training does, because much of that experience occurs in varying circumstances on the job over time. Pengalaman merupakan bagian penting dari pengembangan sebuah manajemen. Memang pengalaman sering memberikan kontribusi lebih terhadap perkembangan seorang manajer dalam pelatihan, karena banyak pengalaman yang terjadi dalam berbagai keadaan pada pekerjaan dari waktu ke waktu. Hunt dan Osborn (2002:11-12) berpendapat ada tiga ketrampilan dalam manajemen, yaitu sebagai berikut: Technical Skills adalah, kemampuan untuk melakukan tugas-tugas khusus. Human Skills adalah pusat untuk pekerjaan manajerial dan kepemimpinan tim selain itu kemampuan untuk bekerja dengan baik dengan orang lain dan Conceptual Skills adalah untuk masalah identitas dan peluang, mengumpulkan dan menginterpretasikan informasi yang relevan, dan membuat pemecahan keputusan yang melayani tujuan organisasi masalah yang baik.

Berdasarkan konsep di atas dapat disintesiskan pengalaman adalah perilaku seseorang yang sudah dilewati untuk pengembangan manajemen yang berguna untuk kondisi masa kini dan kondisi masa datang dengan indikator: memberi kontribusi yang 
berarti, melaksanakan tugas dengan baik, menggunakan keterampilan manajemen, dapat mempengaruhi orang lain, memimpin bawahan.

\section{METODE}

Metode yang digunakan adalah metode survei dengan unit analisis penelitian adalah Kepala SMP Negeri di wilayah Jakarta Timur. Sampel penelitian sebanyak 77 responden diambil dengan menggunakan teknik Simpel Random Sampling. Teknik pengumpulan data dilakukan dengan menggunakan kuesioner dengan skala penilaian (rating scale). Teknik Analisis data yang digunakan secara deskriptif dan inferensial yang digunakan untuk menguji hipotesis dengan menggunakan analisis jalur (path analysis).

\section{HASIL DAN PEMBAHASAN}

Pengaruh kepribadian terhadap efektifitas manajerial

Berdasarkan hasil perhitungan diperoleh koefisien korelasi r13 $=0,652$ dengan koefisien jalur p31=0,507. Dengan demikian terdapat pengaruh langsung variable kepribadian terhadap efektifitas manajerial dinyatakan sangat signifikan.

Seperti dijelaskan Garry (2010:48) mengemukakan bahwa, "the competencies related to managerial effectiveness included personality traits, motives, cognitive skill, and interpersonal skill". Kompetensi yang berkaitan dengan efektivitas manajerial adalah termasuk ciriciri dari kepribadian, motif, keterampilan kognitif, dan keterampilan interpersonal. Pendapat tersebut didukung dengan pendapat Jean Brittain Leslie menyatakan bahwa, "personality stands for an individual's enduring traits that might help explain the kinds of experiences to which he or she is drawn and the kinds of capabilities and role behaviors he or she is most likely to have acquired". Efektivitas manajerial dapat di lihat dari kepribadian seseorang, sifat abadi individu yang mungkin membantu menjelaskan jenis-jenis pengalaman dan jenis-jenis kemampuan dan perilaku peran atau yang telah diperoleh oleh seseorang.

Korelasi kepribadian terhadap efektifitas manajerial kepala sekolah dapat di terima. Artinya jika keakuratan kepribadian kepala sekolah memberikan kenyamanan, ramah, emosionalnya stabil dan terbuka maka efektivitas manajerial kepala sekolah akan meningkat.

\section{Pengaruh pengalaman terhadap efektivitas manajerial}

Berdasarkan hasil perhitungan koefisien korelasi r23 0,546 dengan koefisin jalur p32 0,239. Dengan demikian terdapat pengaruh langsung positif pengalaman terhadap efektifitas manajerial.

Seperti pendapat Richard Hughest (2009:53) menyatakan bahwa, "making the most of experience is key development one's leadership ability ". Pengalaman adalah satu kunci kemampuan pengembangan yaitu kepemimpinan. Pengalaman dengan beragam kondisi dan situasi memberikan kontribusi terhadap pengembangan manajemen, dan membuat para manajer semakin bernilai. Gary Yukl (2010:52) mengungkapkan bahwa, " successfull managers usually had experience in a variety of different personality traits related to managerial effectiveness and advancement". Manajer yang sukses biasanya memiliki pengalaman dalam berbagai ciri kepribadian yang berbeda terkait dengan efektivitas manajerial dan kemajuan. 
Korelasi pengalaman terhadap efektifitas manajerial kepala sekolah dapat di terima. Artinya jika pengalaman kepala sekolah meningkat dengan memberikan kontribusi, melaksanakan tugas dengan baik, menggunakan keterampilan manajemen, mampu mempengaruhi orang lain dan mampu memimpin bawahan maka efektivitas manajerial kepala sekolah akan meningkat.

\section{Pengaruh Kepribadian terhadap Pengalaman}

Berdasarkan hasil perhitungan dapat diperoleh koefisien korelasi r12 $=0,605$ dengan koefisien jalur $\mathrm{p}_{21}=0,605$. Dengan demikian terdapat pengaruh langsung positif kepribadian terhadap pengalaman.

Richard M. Ryckman (2008:3) mengemukakan bahwa, "these perspectives range from eysenck's strong emphasis on the inherited determinants of personality to bandura's stress on the ways in which social-cognitive experiences affect behavior". Perspektif dari kepribadian berkisar pada penekanan yang kuat terhadap faktor penentu dalam mewarisi kepribadian terhadap cara-cara di mana pengalaman sosial kognitif mempengaruhi perilaku. Richard (2008:212) mengemukakan, "although personality traits predispose us to act in certain ways, we can nonetheless learn to modify our behaviors through experience, feedback and reflection".

Walaupun ciri-ciri kepribadian mempengaruhi seseorang untuk bertindak dengan cara tertentu, namun tetap bisa belajar untuk mengubah perilaku melalui pengalaman, umpan balik dan refleksi. Selanjutnya Jean Britain (2002:3) Personality stands for an individual's enduring traits that might help explain the kinds of experiences to which he or she is drawn and the kinds of capabilities and role behaviors he or she is most likely to have acquired. Efektivitas manajerial dapat di lihat dari kepribadian seseorang, sifat abadi individu yang mungkin membantu menjelaskan jenis-jenis pengalaman dan jenisjenis kemampuan dan perilaku peran atau yang telah diperoleh oleh seseorang.

Korelasi kepribadian terhadap pengalaman kepala sekolah dapat di terima. Artinya jika keakuratan kepribadian kepala sekolah memberikan kenyamanan, ramah, emosionalnya stabil dan terbuka maka pengalaman kepala sekolah akan meningkat.

\section{PENUTUP}

Kesimpulan. Berdasarkan analisis terhadap hasil penelitian dapat disampaikan beberapa temuan penelitian sebagai berikut:

1. Terdapat pengaruh Iangsung positif kepribadian terhadap efektivitas manajerial kepala SMP Negeri di wilayah Jakarta Timur.

2. Terdapat pengaruh langsung positif pengalaman terhadap efektivitas manajerial kepala SMP Negeri di wilayah Jakarta Timur.

3. Terdapat pengaruh langsung positif kepribadian terhadap pengalaman kepala SMP Negeri di wilayah Jakarta Timur.

Saran. Berdasarkan saran yang terkait dengan penelitian ini mencakup:

1. Diharapkan para Kepala Sekolah khususnya di wilayah Jakarta Timur dan wilayah DKI Jakarta pada umumnya, hendaknya jangan hanya dipersepsikan sederhana sebagai mobilisasi segala sumber daya pendidikan untuk mencapai tujuan belaka, akan tetapi seyogyanya harus dipandang sebagai fungsi interaksi antara kemampuan, karakter pribadi (personality and emotion) dengan fungsi-fungsi manajemen 
2. Diharapkan Kepala Dinas Pendidikan pemerintah lebih memperhatikan peraturan yang berlaku di Kementerian Pendidikan Nasional untuk setiap tingkatan dan jenis sekolah yang sudah ditetapkan sebagai syarat-syarat yang diperlukan untuk pengangkatan seorang kepala sekolah, hendaknya mengkaji ulang dalam pelaksanaan rekrutmen, seleksi dan pengangkatan kepala sekolah. 


\section{DAFTAR RUJUKAN}

Ainee Juares, What is the Meaning Managerial Effectiveness.

(http:// www.ehow.com/about_6697806_meaning-effectiveness-html

Greenberg Jerald. Managing Behavior in Organizations, Fifth Edistion. New Jersey; USA, 2010.

http://edukasi.kompasiana.com/2013/01/05/persyaratan-kualifikasi-kepemimpinankepala-sekolah-522529.html

Ivancevich, Konopaske, Matteson. Organization Behavior and Management. Eight Edition. New York: McGraw-Hill Companies. 2008.

Jones, Garreth R., Jennifer M. George. Contemporary Management, Four Edition. New York: McGraw Hill, 2006.

Leslie Brittain Jean. Managerial Effectiveness in A Global Context. USA: Center for Creative Leadership. 2002.

Lussier Achua. Effective Leadership, Fourth Edition. South Western: Cengage Learning, 2010.

Luthans Fred. Organizational Behavior. New York: McGraw-Hill. 2008.

Mathis Robert L., John H. Jackson. Manajemen Sumberdaya Manusia. Jakarta: PT Salemba Emban Patria, 2002.

Michael W. Passer dan Ronald E. Smith, Psychology:The Science of Mind and Behavior, Third Edition (New York: McGraw-Hill, 2007), h. 442.

Mukhneri. Manajemen Perkantoran. Jakarta: UNJ Press, 2008.

Mullins Laurie J. Management and Organizational Behaviour. England: Prentice Hall, 2005.

Ryckman Richard M. Theories of Personality. USA: Thomson Higher Education. 2008.

Santrock John W. Educational Psychology. New York: McGraw Hill. 2008.

Sonnentag Sabine. Psychological Management of Individual Performance. Germany: John Wiley\&Sons, 2002.

Yukl Gary. Leadership in Organizations, Seventh Edition. New Jersey: Pearson Education, 2010. 
